\title{
Behaviour and survival of wild Atlantic salmon Salmo salar captured and released while surveillance angling for escaped farmed salmon
}

\author{
Robert J. Lennox ${ }^{1, *}$, Torgeir B. Havn ${ }^{2}$, Eva B. Thorstad ${ }^{2}$, Egil Liberg ${ }^{3}$, \\ Steven J. Cooke', Ingebrigt Uglem ${ }^{2}$
}

${ }^{1}$ Fish Ecology and Conservation Physiology Laboratory, Department of Biology, Carleton University, Ottawa, Ontario K1S 5B6, Canada

${ }^{2}$ Norwegian Institute for Nature Research, PO Box 5685, Torgarden, 7485 Trondheim, Norway

${ }^{3}$ Lakselva Landowners Association, Torget, 9700 Lakselv, Norway

\begin{abstract}
In many Norwegian rivers, spawning stocks are surveyed for escaped farmed salmon with surveillance fishing by rod and reel after the recreational angling season. However, the benefits of surveillance fishing depend on the ability of wild salmon to return to the spawning stock. To evaluate the impacts of surveillance fishing, we captured, radio-tagged and released wild Atlantic salmon Salmo salar in the River Lakselva, Norway, in a surveillance fishery occurring just prior to the spawning period. Among 39 salmon captured, 36 wild fish were tagged and released, whereas 3 were not released (1 bleeding from the gills, 1 farmed, 1 farmed and bleeding). Survival of fish captured by surveillance fishing was high (95\% total survival, $100 \%$ catch-and-release survival). Tagged fish were tracked on average $1.2 \pm 2.8$ (SD) $\mathrm{km}$ from the release site at the end of the experiment during the spawning season, not significantly different from the distance moved by salmon radio tagged throughout the summer during a similar interval (15 September to 24 October 2014). Total movement within $3 \mathrm{~d}$ of release was inferred to average $1.9 \pm 2.1 \mathrm{~km}$, excluding 1 individual that exited the river. Tracking data revealed an immediate behavioural reaction of salmon to surveillance catch-and-release angling, the long-term consequences of which are uncertain. Surveillance fishing may be problematic in rivers with small and vulnerable wild stocks in which a high proportion of the spawning populations is sampled. Surveillance fishing completed with ample time before spawning would be a precautious approach to minimize potential effects during spawning.
\end{abstract}

KEY WORDS: Telemetry - Catch and release ' Species at risk - Biological invasions · Environmental monitoring

\section{INTRODUCTION}

Atlantic salmon Salmo salar populations have declined throughout their range and many have been extirpated (Parrish et al. 1998). Yet, Atlantic salmon is among the most abundant fishes on earth because its high economic value has resulted in intense cultivation and the global proliferation of salmon aquaculture (Gross 1998). These farmed Atlantic salmon

*Corresponding author: robertlennox9@gmail.com have been subjected to artificial selection that has increased the growth rate, fat content and age at maturity, and has reduced stamina, egg size and genetic diversity (Gross 1998, Ferguson et al. 2007). Farmed salmon have been subject to commercial breeding programmes since the early 1970 s, and as a result, now display a wide range of genetic differences to wild conspecifics (Ferguson et al. 2007, Karlsson et al. 2011, Glover et al. 2017). Neverthe-

(C) The authors 2017. Open Access under Creative Commons by Attribution Licence. Use, distribution and reproduction are unrestricted. Authors and original publication must be credited. 
less, farmed salmon may still interbreed with wild salmon, potentially causing significant outbreeding effects (McGinnity et al. 1997, 2003, Fleming et al. 2000, Skaala et al. 2012). Salmon that escape aquaculture facilities enter the ocean and may aggregate with conspecifics at marine feeding areas prior to maturing and migrating into fresh water (Hansen \& Jacobsen 2003). The proportion of escaped farmed salmon in samples of Atlantic salmon from Norwegian rivers varied on average between 9 and $18 \%$ close to the spawning period during 2006 to 2015 (SBSM 2016). The occurrence of escaped farmed salmon in Norwegian rivers across many years has resulted in a significant genetic introgression from farmed salmon in many wild populations (Glover et al. 2012, 2013, Skaala et al. 2012, Karlsson et al. 2016). In the most recent of these studies, Karlsson et al. (2016) reported that significant genetic introgression was observed in 77 out of 147 Norwegian rivers analysed. Furthermore, outside Norway, introgression of escapees has also been observed (Crozier 1993, Clifford et al. 1998). A recent study has shown that gene flow from escaped farmed salmon has altered age and size at maturation in wild Atlantic salmon in many Norwegian rivers (Bolstad et al. 2017).

Intrusion of non-native salmon threatens the genetic integrity and viability of wild salmon (Fleming et al. 2000, McGinnity et al. 2003, Skaala et al. 2012). Anglers may be able to recognize, and subsequently remove, escaped farmed salmon by identifying morphological differences, but genetic analyses or scale reading is necessary for accurate determination in many instances (Lund \& Hansen 1991, Fiske et al. 2005). Scale sampling programmes from recreational fisheries can provide evidence about the extent of farmed salmon intrusion in wild salmon rivers. However, farmed Atlantic salmon are known to enter rivers later in the season than wild fish (e.g. Moe et al. 2016, Svenning et al. 2017), and often after the recreational fishery has closed. Therefore, scale samples obtained during the summer underestimate the extent of farmed salmon in the population. To address this, many rivers have specialized surveys of the spawning stock for escaped farmed fish using rod and reel in the autumn, a time when the highest number of fish have entered the river, to collect scales from a more representative sample of the spawning population in the river. Inevitably, many wild Atlantic salmon are captured by these surveillance fisheries, which are intended to be released unharmed so that they can return to pre-spawning and spawning activities.
Survival of Atlantic salmon released by rod and reel is consistently high (Lennox et al. 2017), but there is evidence that recreational angling can alter the behaviour of wild Atlantic salmon during their upriver migration (Mäkinen et al. 2000, Thorstad et al. 2003, Havn et al. 2015). Many Atlantic salmon captured in summer fisheries are captured during the upriver movement phase of migration, which begins after river entry. Fish captured in surveillance fisheries are likely to have completed upriver movement and be in the holding phase of the migration, at or near the spawning destination (Økland et al. 2001). Capture, handling (including scale removal for analysis) and release of wild Atlantic salmon in autumn surveillance fisheries may result in mortality of released fish or elicit similar behavioural responses such as long movements away from the holding sites. Success of surveillance fisheries is contingent on balancing the benefits of enumerating the intrusion of farmed salmon against the potential impacts that could be imparted on wild salmon caught and released close to the time of spawning, which remains poorly understood. To determine whether wild Atlantic salmon captured by autumn surveillance fishing with rod and reel are negatively impacted by catch-and-release angling, we tagged salmon with radio transmitters after capture and scale sampling and monitored in-river movements until the spawning season.

\section{MATERIALS AND METHODS}

\section{Study site}

The study was performed in the River Lakselva, Finnmark, Norway. Lakselva discharges into the Porsanger Fjord and has $45 \mathrm{~km}$ available to wild Atlantic salmon. Most of the salmon spawn in river reaches below 2 lakes (Lennox et al. 2016). The recreational fishing season for Atlantic salmon concludes on $31 \mathrm{Au}-$ gust, and fishing for sea trout Salmo trutta concludes on 15 September. Surveillance fishing is then conducted until approximately 2 wk prior to peak spawning. For this study, surveillance fishing was conducted between 19 September and 2 October 2016. During this period, water temperatures were (mean $\pm \mathrm{SD}$ ) 9.6 $\pm 0.6^{\circ} \mathrm{C}$ (range $=8.4-10.7^{\circ} \mathrm{C}$ ) as measured by a water temperature logger (HOBO Pendant Temperature/ Light Data Logger 64K-UA-002-64) deployed in a shaded area of the river at 9 river kilometres (rkm, i.e. $\mathrm{km}$ from the river mouth) at a depth of $2 \mathrm{~m}$ from the surface. 


\section{Experiments}

All tagged salmon were captured by 3 anglers. Sex was visually determined by secondary sexual traits such as development of kype and colouration. Our research was conducted on 19 female (mean $\pm \mathrm{SD}=98 \pm$ $20 \mathrm{~cm}$ total length [TL]; range $=58-116 \mathrm{~cm} \mathrm{TL}$ ) and 20 male $(77 \pm 21 \mathrm{~cm} \mathrm{TL}$; range $=55-113 \mathrm{~cm})$ Atlantic salmon captured by surveillance fishing. Five individuals ( $65 \pm 8 \mathrm{~cm} \mathrm{TL} ; 4$ male, 1 female) were considered to be freshly entered into the river based on their silver colouration; 1 of these fish had sea lice attached with egg strings, which indicates that it had very recently entered fresh water. Salmon were captured by artificial flies $(\mathrm{N}=19)$ and lures (i.e. metal spoons; $\mathrm{N}=$ 20 ). After fighting for an average $( \pm \mathrm{SD})$ of $321 \pm 270 \mathrm{~s}$, salmon were landed in a knotless mesh landing net $(\mathrm{N}=37)$ or tailed $(\mathrm{N}=2)$ and were rapidly transferred into a water-filled PVC tube by placing the fish into a plastic sling designed to hold fish with enough water to respire. The fish's eyes were covered by a damp towel in the tube to keep it calm. Each fish was measured (TL in $\mathrm{cm}$ ), sexed, assessed for colour (silver, intermediate or brown) and tagged. Tags were rectangular $(21 \times 52 \times 11 \mathrm{~mm}$, mass in air $=15 \mathrm{~g})$ coded radio transmitters (Advanced Telemetry Systems) in the frequency range 142.144-142.484 MHz. The tags were attached by passing steel wire $(0.8 \mathrm{~mm})$ through hypodermic needles inserted between the pterygiophore bones. A white plastic backplate was placed on the opposite side from the tag (see Lennox et al. 2015, 2016). After tagging, 5 to 8 scales were removed from the fish's right side, posterior to the dorsal fin near the midline using needle-nose pliers; these scales were used to determine the origin of the fish as wild or escaped farmed. Total exposure to air from landing the fish to release was (mean $\pm \mathrm{SD}$ ) $2 \pm 2 \mathrm{~s}$ (range $=0-7 \mathrm{~s}$ ). Fish were held in water for $62 \pm 82 \mathrm{~s}$ (range $=0-6 \mathrm{~min}$ ) before they swam away volitionally.

The position of each fish in the river was determined at $1 \mathrm{~h}, 1 \mathrm{~d}, 2 \mathrm{~d}$ and $3 \mathrm{~d}$ after capture as well as once weekly until 24 October. Positions were determined using a vehicle-mounted ATS R4500CD coded receiver datalogger attached to either a dipole antenna (Magnetic Roof-Mount Dipole, Laird Technologies) or a 4-element Yagi antenna for precise determination. To ensure adequate coverage of the river and to note any fish that moved out of the tracking area, directional stationary logging stations mounted with two 6-element Yagi antennas each were also established near the confluence of the river with the fjord at $4 \mathrm{rkm}$ and at $20 \mathrm{rkm}$, beyond which access by road is limited. Fine-scale positioning permitted the identification of upstream movement of fish, indicating survival and also to calculate movement from the capture site after sampling. Observation by snorkeling or sudden position movements provoked by snorkeling were used to confirm survival (on 6 and 23 October 2016) for fish that were not recorded to move upstream between tracking surveys.

\section{Data analysis}

Catch-and-release mortality was calculated as the percentage of fish determined to have died based on the radio tracking after release. Fish that moved upriver immediately after release required an additional upriver movement occurring more than $2 \mathrm{~d}$ after release to be considered a survivor. Snorkel surveys were conducted to verify survival of any salmon for which there was doubt about survival. Total mortality was calculated by adding delayed mortality and immediate mortality (i.e. the sample fish that were killed due to extensive bleeding).

Tracking data were imported into ArcGIS software (ESRI 2011) to calculate the distance from the river mouth of each position in rkm. Positions for each fish were then used to determine the extent of downriver movement immediately after release and the final position in the river relative to the release location. Because fish were tracked at fixed intervals in the first $3 d$, we could infer the minimum movement in this period by summing the absolute values of the changes in position of fish in the river from each tracking point. Final positions of fish compared to the release site were calculated and compared to the change in position of fish tagged in the summer recreational fishery in 2014 (Lennox et al. 2016). The 2014 data comprised 21 fish that were tracked on 24 October and 15 September, which is a comparable period to that in 2016. However, fish in 2014 were tagged during the summer (13 July to 29 August) and we therefore interpreted movement of those fish as expected movement of fish during this period. We excluded 1 fish from 2016 that exited the river and compared the relative movement of fish in the SeptemberOctober period for salmon tagged in the 2 experiments with a Welch 2-sample $t$-test implemented with the t.test function in R (R Core Team 2017).

To determine which factors influenced movement of salmon from the release site within the $3 \mathrm{~d}$ fixed interval tracking period, generalized least squares regression was implemented with the gls function in the $\mathrm{R}$ package nlme (Pinheiro et al. 2016). The model is based on 32 salmon given that 4 individuals had 
incomplete tracking records within $3 \mathrm{~d}$. The full model is presented as the final model. Generalized least squares regression was used instead of multiple linear regression because it can incorporate variance structures that account for heteroscedasticity in model residuals (Pinheiro et al. 2016). The dependent variable, inferred distance moved within $3 \mathrm{~d}$, was log transformed to account for non-normality of residuals and a varIdent variance structure was incorporated in the model to account for heteroscedasticity of the bleeding predictor variable, which was coded as a factor (Pinheiro et al. 2016). In all statistical analyses, significance was assessed at $\alpha=0.05$.

\section{RESULTS}

Among the 39 Atlantic salmon captured, 2 individuals incurred injury to the gills and were not released (1 of farmed origin, 1 wild). One additional individual was determined to be of farmed origin based on external traits and was also not released (farmed origin of this individual was later confirmed by expert scale analysis); all other individuals were confirmed by scale analysis to be of wild origin. Therefore, the sample of tagged fish consisted of 36 wild Atlantic salmon (mean $87 \pm 20 \mathrm{~cm} \mathrm{TL}$; range $=55-116 \mathrm{~cm}$ ). Every salmon that was released was confirmed to have survived the surveillance fishing based on in-river movements made after release, observation by snorkeling and/or by sudden changes in position provoked by snorkeling. Catch-and-release survival was therefore $100 \%$. Total survival of the fish captured during the monitoring was $95 \%$, considering that 2 individuals were killed due to injuries. One individual (1 sea winter $62 \mathrm{~cm}$ male, brown coloured at release) was recorded passing by the stationary logger near the river mouth $13 \mathrm{rkm}$ downriver from the release location before it disappeared from the river, and most likely did not spawn in Lakselva. Movements by this fish were determined to be volitional, and not the passive drifting of a fish carcass, based on the periodic up- and down-river movements recorded by the stationary logger.

Three of the fish that were released were bleeding slightly; of these, 2 were captured by lures and 1 by a fly. One of the bleeding fish shook the hook out while in the net, indicating that it was not likely lodged in a criti- cal location, 1 was hooked in both the upper and lower jaws simultaneously, and 1 was hooked in the corner of the jaw.

Within $1 \mathrm{~h}$ of release, salmon were on average ( $\pm \mathrm{SD}$ ) $0.04 \pm 0.12 \mathrm{rkm}$ downriver from the release site (range $=-0.52$ to $0.17 \mathrm{rkm}$; Table 1$)$, although 17 $(47 \%)$ were approximately in the same position $( \pm 20 \mathrm{~m})$ as where they were released and $75 \%$ were within $\pm 100 \mathrm{~m}$ (Fig. 1). One day after release, 33\% were within $\pm 100 \mathrm{~m}$ of the release location; 1 moved upriver $2.5 \mathrm{rkm}$ and another moved down $2.5 \mathrm{rkm}$

Table 1. Summary of distance (river $\mathrm{km}, \mathrm{rkm}$ ) moved by Atlantic salmon Salmo salar released during surveillance fishing. Each fish was tracked $1 \mathrm{~h}, 1 \mathrm{~d}, 2 \mathrm{~d}$ and $3 \mathrm{~d}$ after release. Mean, median, standard deviation (SD) and range of relative distances and absolute distances from the release site are presented. Number of fish tracked in each sample is also included because some positions were not available due to tracking error. For the final positions, 1 fish that exited the river was excluded from the total

\begin{tabular}{|lrrrrr|}
\hline Timepoint & $\mathrm{N}$ & $\begin{array}{c}\text { Mean } \\
\text { (rkm) }\end{array}$ & $\mathrm{SD}$ & $\begin{array}{c}\text { Median } \\
\text { (rkm) }\end{array}$ & $\begin{array}{c}\text { Range } \\
\text { (rkm) }\end{array}$ \\
\hline Relative & & & & & \\
$1 \mathrm{~h}$ & 36 & -0.04 & 0.12 & 0.00 & $-0.52-0.17$ \\
$1 \mathrm{~d}$ & 36 & 0.15 & 0.92 & 0.00 & $-2.50-2.50$ \\
$2 \mathrm{~d}$ & 34 & 0.33 & 1.86 & 0.12 & $-4.74-5.23$ \\
$3 \mathrm{~d}$ & 32 & 0.23 & 1.86 & 0.12 & $-6.38-3.47$ \\
Final & 35 & 1.23 & 2.79 & 0.29 & $-2.98-11.11$ \\
& & & & & \\
Absolute & & & & & \\
$1 \mathrm{~h}$ & 36 & 0.07 & 0.11 & 0.00 & $0.00-0.52$ \\
$1 \mathrm{~d}$ & 36 & 0.58 & 0.71 & 0.27 & $0.00-2.50$ \\
$2 \mathrm{~d}$ & 34 & 1.20 & 1.44 & 0.58 & $0.00-5.23$ \\
$3 \mathrm{~d}$ & 32 & 1.13 & 1.48 & 0.50 & $0.00-6.38$ \\
Final & 35 & 1.82 & 2.44 & 0.76 & $0.02-11.11$ \\
\hline
\end{tabular}

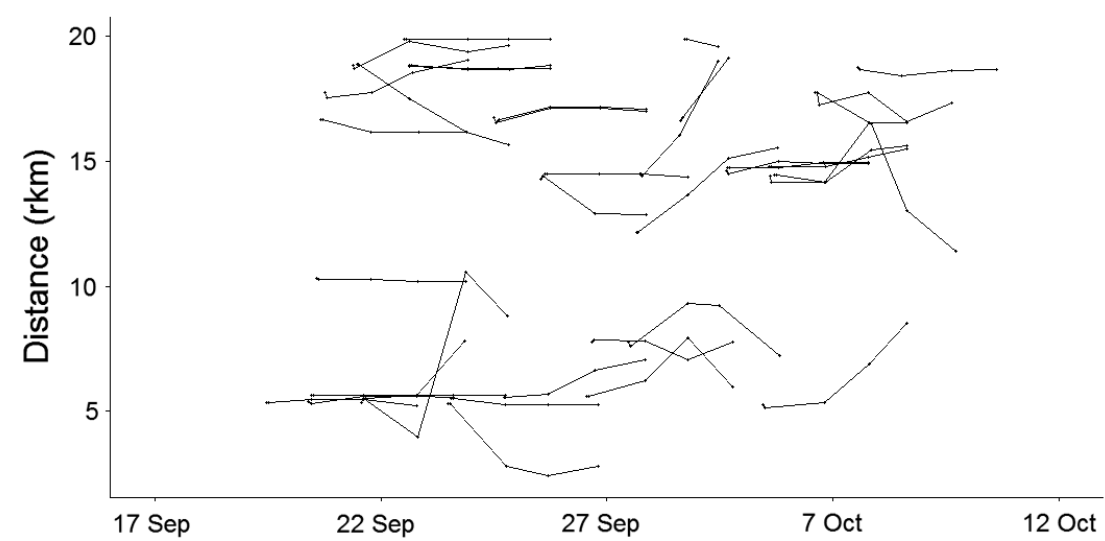

Fig. 1. Changes in position of individual Atlantic salmon Salmo salar caught by surveillance fishing in Lakselva, Norway in 2016. Positions were recorded by manual tracking $1 \mathrm{~h}, 1 \mathrm{~d}, 2 \mathrm{~d}$ and $3 \mathrm{~d}$ after release. Distances are presented relative to the river mouth (river $\mathrm{km}, \mathrm{rkm}$ ) 


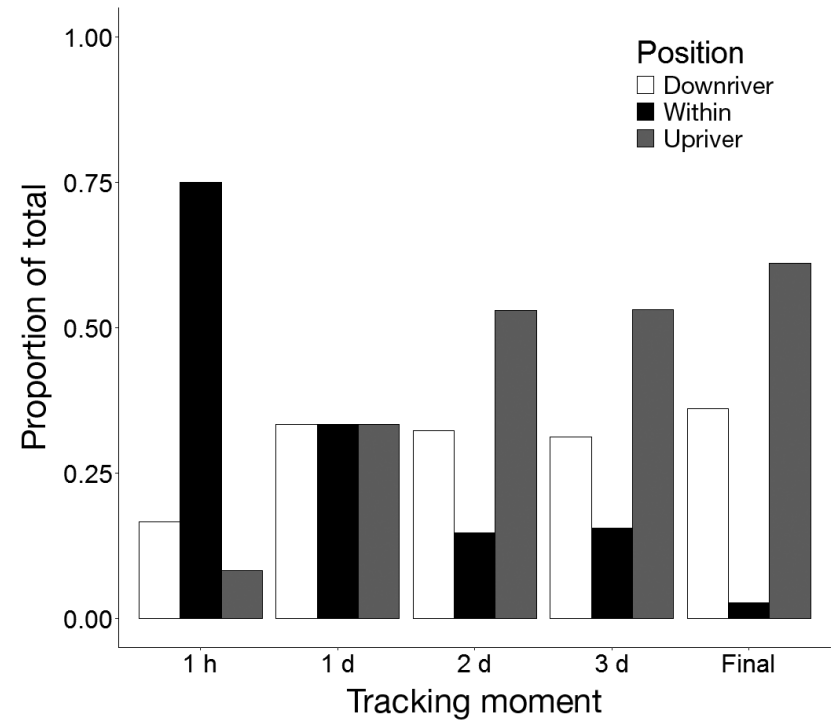

Fig. 2. Proportion of Atlantic salmon Salmo salar positioned downriver, within $100 \mathrm{~m}$, or upriver of the release location after $1 \mathrm{~h}, 1 \mathrm{~d}, 2 \mathrm{~d}, 3 \mathrm{~d}$ and at the end of the study

(Fig. 2). After Day 2, only $15 \%$ were within $\pm 100 \mathrm{~m}$ and after Day 3, 19\% were within $\pm 100 \mathrm{~m}$. The final position of salmon, taken at the end of October, was on average $( \pm \mathrm{SD})$ above the release location by $1.23 \pm$

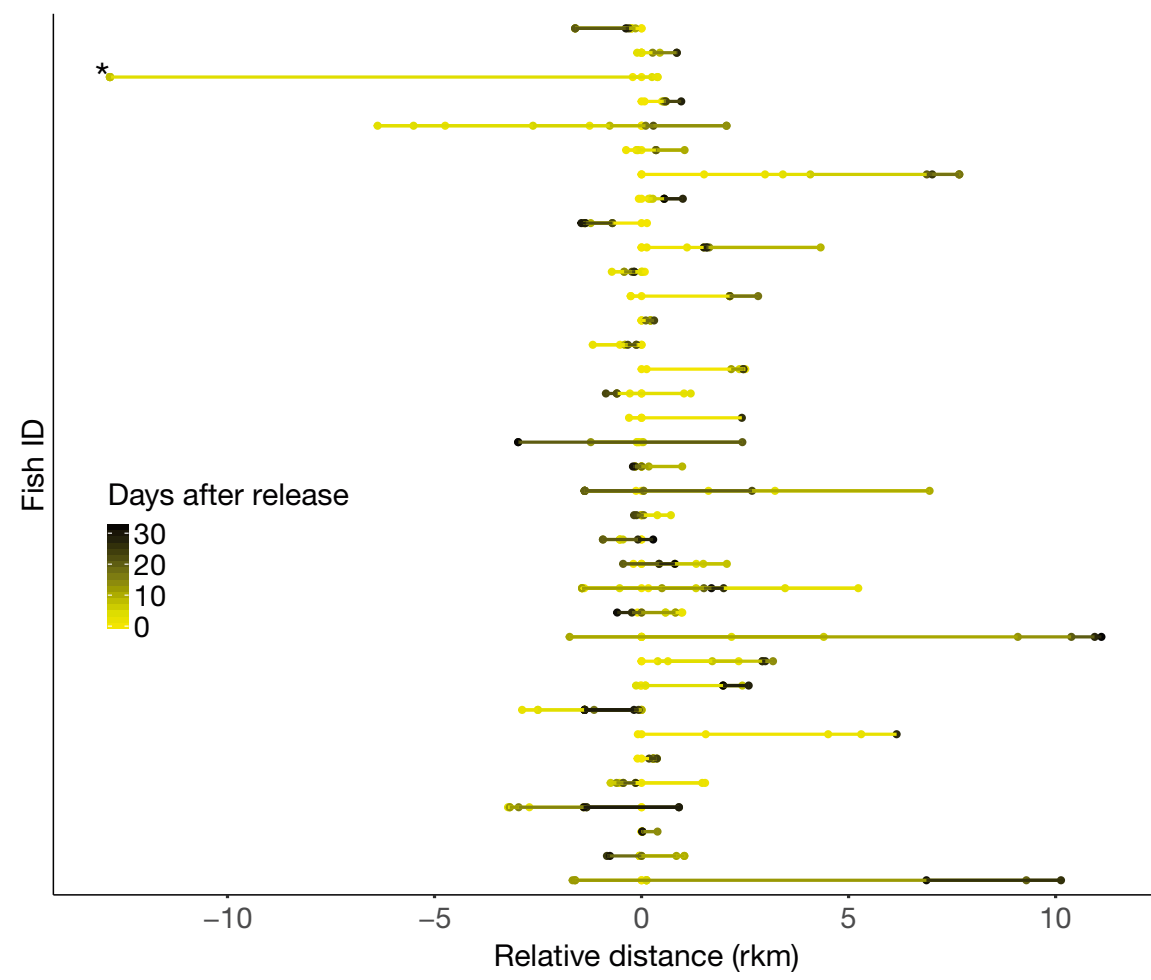

Fig. 3. Relative distances travelled by Atlantic salmon Salmo salar captured in a surveillance fishery. The colour scale indicates the temporal change in position of fish in the river based on fixed interval tracking and logging station data in days after tagging. The asterisk demarcates the fish that exited the river prior to spawning
$2.80 \mathrm{rkm}$ (range $=-2.98$ to $11.11 \mathrm{rkm}$ ), and only 1 individual $(3 \%)$ was within $100 \mathrm{~m}$ of the release site (Fig. 3). More fish moved upriver than downriver from the release site, suggesting that movements were volitional rather than the result of being swept downcurrent. The net change in position was not significantly different for the 2016 fish captured by surveillance fishing compared to fish captured in the summer recreational fishery in $2014(t=-0.89, \mathrm{df}=36.84, \mathrm{p}=$ 0.38 ; Fig. 4). The farthest point recorded from the release site was on average $( \pm \mathrm{SD}) 2.19 \pm 2.87 \mathrm{rkm}$, although the median was $0.96 \mathrm{rkm}$.

The inferred distance moved within $3 \mathrm{~d}$ of release was on average $( \pm \mathrm{SD}) 1.93 \pm 2.11 \mathrm{~km}$. Silver coloured and male fish moved more than brown and female fish, but the differences were only weakly significant (Table 2). No other predictors were significant in the model (Table 2).

\section{DISCUSSION}

Physical and physiological impacts of capture and handling result in some mortality of fish captured in fisheries (Arlinghaus et al. 2007, Lennox et al. 2017). It is therefore expected that the surveillance fishery would result in the mortality of some wild fish, and, similar to other studies of Atlantic salmon, that this mortality would be infrequent. Immediate mortality of salmon in the surveillance fishery, resulting from damage caused by the hook, was similar to that in other studies (3-10\%; Havn et al. 2015, Lennox et al. 2015, 2016). Delayed mortality of salmon in the surveillance fishery was nil, which is consistent with other assessments using telemetry that have generally identified infrequent post-release mortality, with high water temperature being the most important predictor of post-release mortality (Lennox et al. 2017). Water temperatures in September and October are cooler than during the summer and therefore high water temperature is not likely to be a risk factor for surveillance fishing mortality. This does not preclude the occasional immediate mortality event such as we observed here, but in general, mor- 


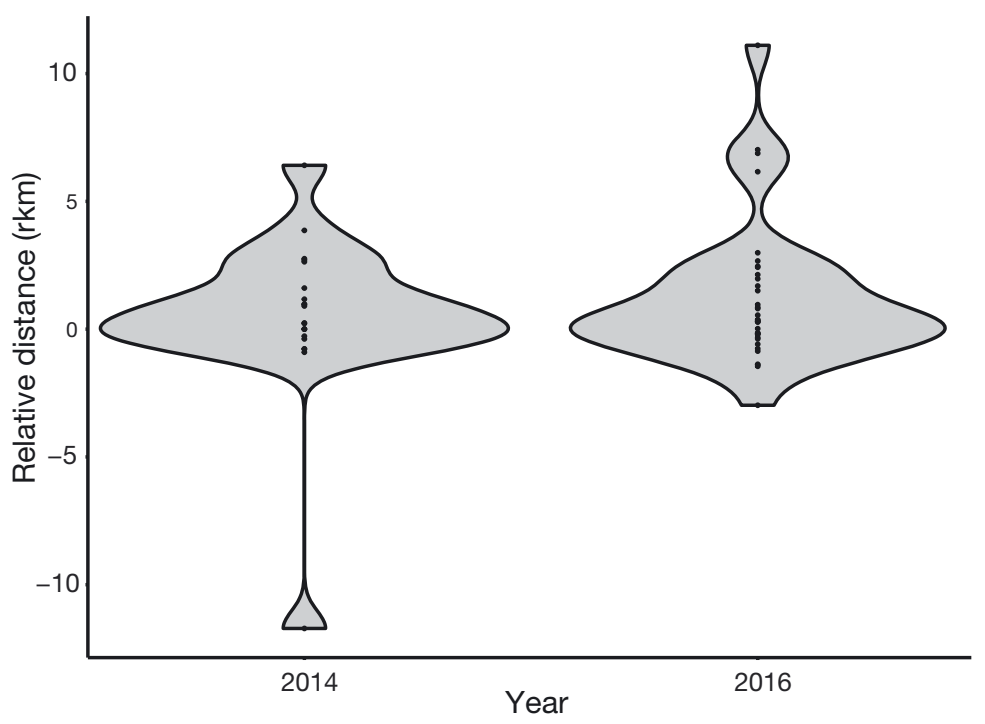

Fig. 4. Positions of Atlantic salmon Salmo salar released from a summer recreational fishery $\left(\mathrm{N}_{2014}=21\right)$ and surveillance fishery $\left(\mathrm{N}_{2016}=\right.$ 35 , having excluded 1 fish that exited prior to spawning). Positions for the 2014 fish were taken on 24 October 2014 and are relative to positions taken on 15 September 2014. Positions for 2016 are the final positions in the river taken on 22-24 October relative to the release site. Points are overlaid within the violin plots to show the positions of individual fish

tality in fall surveillance fisheries would appear to be negligible.

Capture and handling are known to cause biochemical disturbances in fish (see Thorstad et al. 2003 for data on Atlantic salmon blood analyses in response to angling), which can manifest as behavioural anomalies or impairment (Mäkinen et al. 2000, Thorstad et al. 2003, Havn et al. 2015). Even though all released salmon survived the surveillance fishery,

Table 2. Generalized least squares regression of logtransformed movement within $3 \mathrm{~d}$ by Atlantic salmon Salmo salar released by surveillance anglers during the autumn fishing season. P-values are relative to the reference levels of categorical variables (reference levels for each factor: Gear $=$ Fly,

Sex $=$ Female , Colour $=$ Brown, Bleeding $=$ Negative $)$

\begin{tabular}{|lcrc|}
\hline Fixed effect & Estimate $\pm \mathrm{SE}$ & \multicolumn{1}{c}{$t$} & $\mathrm{p}$ \\
\hline (Intercept) & $-11.83 \pm 16.35$ & -0.72 & 0.48 \\
Length & $0.01 \pm 0.02$ & 0.54 & 0.60 \\
Fight time & $0.00 \pm 0.00$ & 0.14 & 0.89 \\
Recovery time & $0.00 \pm 0.00$ & -0.71 & 0.49 \\
Release date & $0.04 \pm 0.06$ & 0.60 & 0.55 \\
Gear (Lure) & $0.25 \pm 0.47$ & 0.53 & 0.60 \\
Sex (Male) & $1.30 \pm 0.70$ & 1.86 & 0.08 \\
Colour (Intermediate) & $-0.55 \pm 0.86$ & -0.64 & 0.53 \\
Colour (Silver) & $1.37 \pm 0.70$ & 1.97 & 0.06 \\
Bleeding (Positive) & $1.41 \pm 0.88$ & 1.59 & 0.13 \\
& & & \\
\hline
\end{tabular}

a majority of them were beyond $100 \mathrm{~m}$ from where they were holding in preparation of spawning. This is suggestive of an acute disturbance caused by capture and handling, which is similar to the behavioural responses of salmon to catch-and-release angling in the summer recreational fisheries. Radio tracking of salmon released from an experimentally extended recreational fishery in the Dee River also identified high survival of fish captured later in the season and with similar up- and downriver movement away from the release site (Dee River Trust 2010). However, salmon probably do not normally move away from holding sites in this season; radio-tagged salmon caught in bag nets in the fjord and released in July moved $0.36 \mathrm{rkm}$ (males) or $0.80 \mathrm{rkm}$ (females) between 11 October and 1 November in the River Alta, which is close to Lakselva (Økland et al. 1995). Although these surveys were performed later in Alta than our study in Lakselva, the total distances were inferred from more frequent tracking surveys, observing less movement than fish captured in the Lakselva surveillance fishery. Salmon that are holding position prior to spawning are likely maintaining a position near their eventual spawning site and not necessarily on it (Økland et al. 2001, Richard et al. 2014). Movement away from holding pools therefore does not necessarily suggest a loss of territory, especially given that individuals move among pools during the spawning season (Taggart et al. 2001), and a comparison to the movement exhibited by salmon in 2014 indicated no major differences in displacement.

It is notable that 5 salmon captured in the surveillance fishery were silver in colour, suggesting that they had recently entered the river. Most salmon have premature migration, entering rivers weeks or months before spawning to stage near spawning grounds (Økland et al. 2001, Quinn et al. 2015). Silver salmon moved more than brown salmon, which makes sense given that these fish would be more likely to be in the active migration phase, on the way to spawning grounds, than holding near spawning territories (Økland et al. 2001). However, the movements made by the silver salmon were not unidirectional towards upriver territory and included downstream running. Downstream running and erratic movement are believed to be symptoms of a stress response by salmon (Mäkinen et al. 2000, Havn et al. 2015). Although Thorstad et al. (2007) identified no differences in behavioural responses or survival after 
catch and release of silver and brown salmon, salmon might have differences in the stress responsiveness at different stages of reproductive maturity. For example, Raby et al. (2013) described an attenuated stress response of Pacific salmon Oncorhynchus gorbuscha and O. keta on spawning grounds, suggesting a change in physiological pathways later in migration as fish prepare for spawning.

Escaped farmed Atlantic salmon represent an immediate and growing threat to the conservation of wild salmon populations (Karlsson et al. 2016, Forseth et al. 2017, Glover et al. 2017). Scale sampling showed that $5 \%$ of the salmon captured during surveillance fishing were of farmed origin, which is concerning given that there are no farms in the immediate vicinity. The genetic integrity of the Lakselva population was recently characterized as being of moderate quality due to genetic introgression of farmed salmon in the wild population (Forseth \& Thorstad 2016, Karlsson et al. 2016). Maintaining records of farmed salmon in rivers can assist with longterm tracking of trends in wild salmon conservation, particularly in prioritizing conservation efforts towards rivers where intrusion by farmed salmon is most frequent.

Given that the goal of any monitoring activity should be to minimize impacts on wild fish, other methods could be compared to sampling with rod and reel. However, surveillance fishing appears to be a relatively low-impact method of surveying the spawning stock for farmed fish. Although we observed $100 \%$ survival of fish that were released, there was some immediate mortality of fish captured in the surveillance fishery, and we observed acute disturbances to the behaviour, specifically movement away from the release location that is probably beyond the normal activity that salmon engage in during this period. In addition, 1 fish exited the river and was probably lost from the spawning population. Ultimately, the net change in position from September to spawning at the end of October was not different from expected movement based on fish tagged in the early season in 2014, suggesting that most salmon released by surveillance fisheries can return to the spawning population. Future research should make a more direct comparison with a control group to determine what the expected movement of fish is during the autumn and establish to what extent they move within the river. Research should also shift to a more direct quantification of fitness by assessing the spawning success of fish released from the surveillance fishery. Chronic stressors have repeatedly been linked to reproductive suppression or failure in salmonids (Weiner et al. 1986, Pickering et al. 1987, Campbell et al. 1992). Recreational angling, however, is an acute stressor, and some evidence suggests that fish exposed to acute stressors, even proximate to spawning, can restore homeostasis relatively quickly, which would attenuate any longer-term effects. Pickering et al. (1987) measured decreasing androgenic hormones in the blood of brown trout Salmo trutta, which recovered within $24 \mathrm{~h}$ in captivity. Correspondingly, Davidson et al. (1994) and Booth et al. (1995) calculated high hatching success of eggs laid and fertilized by Atlantic salmon subjected to simulated late-season angling. Although this is the best available evidence as to whether salmon captured in surveillance fisheries would likely contribute viable progeny, impacts of long-term survival are unknown and deserve further consideration given that hatching success is not an ultimate measure of offspring fitness (e.g. Berntsen \& Bech 2016).

In the absence of direct measurements of fitness impairments caused by surveillance fishing, an appropriate precaution would be to maintain a buffer period between the end of surveillance fishing and the initiation of spawning to provide salmon with time to recover. Future studies incorporating a control group will assist with defining an appropriate buffer period, including physiological (e.g. Raby et al. 2015) and behavioural assessments (e.g. Whitney et al. 2016) of the recovery time of salmon after exercise. In general, longer buffer periods will be best but this must be considered against the run timing of farmed fish to ensure a representative sample (Moe et al. 2016, Svenning et al. 2017). Farmed salmon also tend to have a different distribution within the river than wild fish, and have been observed migrating farther upriver than wild fish (Moe et al. 2016); therefore, efforts to refine surveillance fishing methods may be necessary to further ensure representative sampling.

Despite the behavioural disturbance observed among the salmon in Lakselva, capture and release of a small population sample for surveillance fishing is unlikely to affect the spawning in rivers with large stocks. Indeed, any negative impacts may be offset by benefits provided by collecting important information about escaped farmed salmon intrusion that allows for remediation or restoration and contributes to good fisheries management and long-term sustainability. Where rivers are considered to have vulnerable stocks (e.g. small spawning biomass), surveillance fishing could be more damaging to the population, because it is necessary to sample a relatively high proportion of the spawning populations in 
such rivers to obtain a statistically justifiable sample size compared to rivers with large wild stocks. Caution should be exercised when implementing surveillance fisheries with river-specific conservation needs and objectives of foremost consideration, particularly in balancing the expected gains in terms of information about the intrusion of escaped farmed salmon in rivers.

Acknowledgements. We are grateful to the Lakselva Grunneierforening for their assistance and expertise while working in Lakselv, and we thank the Norwegian Environment Agency and the Norwegian Directorate of Fisheries for funding the study. R.J.L. was supported by a Canada Graduate Scholarship from the Natural Sciences and Engineering Research Council of Canada (NSERC).

\section{LITERATURE CITED}

Arlinghaus R, Cooke SJ, Lyman J, Policansky D and others (2007) Understanding the complexity of catch-andrelease in recreational fishing: an integrative synthesis of global knowledge from historical, ethical, social, and biological perspectives. Rev Fish Sci 15:75-167

Berntsen HH, Bech C (2016) Incubation temperature influences survival in a small passerine bird. J Avian Biol 47: 141-145

Bolstad GH, Hindar K, Robertsen G, Jonsson B and others (2017) Gene flow from domesticated escapes alters the life history of wild Atlantic salmon. Nat Ecol Evol 1:0124

Booth RK, Kieffer JD, Tufts BL, Davidson K, Bielak AT (1995) Effects of late-season catch and release angling on anaerobic metabolism, acid-base status, survival, and gamete viability in wild Atlantic salmon (Salmo salar). Can J Fish Aquat Sci 52:283-290

Campbell PM, Pottinger TG, Sumpter JP (1992) Stress reduces the quality of gametes produced by rainbow trout. Biol Reprod 47:1140-1150

Clifford SL, McGinnity P, Ferguson A (1998) Genetic changes in Atlantic salmon (Salmo salar) populations of northwest Irish rivers resulting from escapes of adult farm salmon. Can J Fish Aquat Sci 55:358-363

Crozier WW (1993) Evidence of genetic interaction between escaped farmed salmon and wild Atlantic salmon (Salmo salar L.). Aquaculture 113:19-29

Davidson K, Hayward J, Hambrook M, Bielak AT, Sheasgreen J (1994) The effects of late-season angling on gamete viability and early fry survival in Atlantic salmon. Can Tech Rep Fish Aquat Sci 1982:1-12

Dee River Trust (2010) Monitoring of the River Dee fishery season extension 2008 - 2010. www.riverdee.org.uk/

ESRI (Environmental Systems Research Institute) (2011) ArcGIS Desktop: release 10. Environmental Systems Research Institute, Redlands, CA

Ferguson A, Fleming I, Hindar K, Skaala $\varnothing$, McGinnity $P$, Cross TF, Prodöhl P (2007) Farm escapes. In: Verspoor E, Stradmeyer L, Nielsen JL (eds) The Atlantic salmon: genetics, conservation and management. Blackwell Publishing Ltd, Oxford, p 357-398

Fiske P, Lund RA, Hansen LP (2005) Identifying fish farm escapees. In: Cadrin SX, Friedland KD, Waldman JD (eds) Stock identification methods. Elsevier Academic
Press, Amsterdam, p 659-680

Fleming IA, Hindar K, Mjølnerød IB, Jonsson B, Balstad T, Lamberg A (2000) Lifetime success and interactions of farm salmon invading a native population. Proc Biol Sci 267:1517-1523

Forseth T, Thorstad EB (eds) (2016b) Klassifisering av 104 laksebestander etter kvalitetsnorm for villaks (Classification of 104 salmon populations according to the quality norm for wild salmon). Themed Report 4. Vitenskapelig råd for lakseforvaltning, Trondheim

Forseth T, Barlaup BT, Finstad B, Fiske P and others (2017) The major threats to Atlantic salmon in Norway. ICES J Mar Sci 74:1496-1513

Glover KA, Quintela M, Wennevik V, Besnier F, Sørvik AG, Skaala Ø (2012) Three decades of farmed escapees in the wild: a spatio-temporal analysis of Atlantic salmon population genetic structure throughout Norway. PLOS ONE 7:e43129

Glover KA, Pertoldi C, Besnier F, Wennevik V, Kent M, Skaala Ø (2013) Atlantic salmon populations invaded by farmed escapees: quantifying genetic introgression with a Bayesian approach and SNPs. BMC Genet 14:74

Glover KA, Solberg MF, McGinnity P, Hindar K and others (2017) Half a century of genetic interaction between farmed and wild Atlantic salmon: status of knowledge and unanswered questions. Fish Fish (in press), doi: 10. 1111/faf.12214

F Gross MR (1998) One species with two biologies: Atlantic salmon (Salmo salar) in the wild and in aquaculture. Can J Fish Aquat Sci 55:131-144

*Hansen LP, Jacobsen JA (2003) Origin and migration of wild and escaped farmed Atlantic salmon, Salmo salar L., in oceanic areas north of the Faroe Islands. ICES J Mar Sci 60:110-119

*Havn TB, Uglem I, Solem Ø, Cooke SJ, Whoriskey FG, Thorstad EB (2015) The effect of catch-and-release angling at high water temperatures on behaviour and survival of Atlantic salmon Salmo salar during spawning migration. J Fish Biol 87:342-359

Karlsson S, Moen T, Lien S, Glover K, Hindar K (2011) Generic genetic differences between farmed and wild Atlantic salmon identified from a 7K SNP-chip. Mol Ecol Resour 11:247-253

Karlsson S, Diserud OH, Fiske P, Hindar K (2016) Widespread genetic introgression of escaped farmed Atlantic salmon in wild salmon populations. ICES J Mar Sci 73: 2488-2498

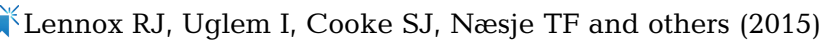
Does catch-and-release angling alter the behavior and fate of adult Atlantic salmon during upriver migration? Trans Am Fish Soc 144:400-409

Lennox RJ, Cooke SJ, Diserud OH, Havn TB and others (2016) Use of simulation approaches to evaluate the consequences of catch-and-release angling on the migration behaviour of adult Atlantic salmon (Salmo salar). Ecol Model 333:43-50

尔 Lennox RJ, Cooke SJ, Davis CR, Gargan P and others (2017) Pan-Holarctic assessment of post-release mortality of angled Atlantic salmon Salmo salar. Biol Conserv 209: 150-158

Kund RA, Hansen LP (1991) Identification of wild and reared Atlantic salmon, Salmo salar L., using scale characters. Aquacult Res 22:499-508

Mäkinen TS, Niemelä E, Moen K, Lindström R (2000) Behaviour of gill-net and rod-captured Atlantic salmon (Salmo 
salar L.) during upstream migration and following radio tagging. Fish Res 45:117-127

McGinnity P, Stone C, Taggart JB, Cooke D and others (1997) Genetic impact of escaped farmed Atlantic salmon (Salmo salar L.) on native populations: use of DNA profiling to assess freshwater performance of wild, farmed, and hybrid progeny in a natural river environment. ICES J Mar Sci 54:998-1008

McGinnity P, Prodöhl P, Ferguson A, Hynes R and others (2003) Fitness reduction and potential extinction of wild populations of Atlantic salmon Salmo salar as a result of interactions with escaped farm salmon. Proc Biol Sci 270: $2443-2450$

Moe K, Næsje TF, Haugen TO, Ulvan EM, Aronsen T, Sandnes T, Thorstad EB (2016) Area use and movement patterns of wild and escaped farmed Atlantic salmon before and during spawning in a large Norwegian river. Aquacult Environ Interact 8:77-88

Økland F, Heggeberget TG, Jonsson B (1995) Migratory behaviour of wild and farmed Atlantic salmon (Salmo salar) during spawning. J Fish Biol 46:1-7

Økland F, Erkinaro J, Moen K, Niemelä E, Fiske P, McKinley RS, Thorstad EB (2001) Return migration of Atlantic salmon in the River Tana: phases of migratory behaviour. J Fish Biol 59:862-874

Parrish DL, Behnke RJ, Gephard SR, McCormack SD, Reeves GH (1998) Why aren't there more Atlantic salmon (Salmo salar)? Can J Fish Aquat Sci 55:281-287

Pickering AD, Pottinger TG, Carragher J, Sumpter JP (1987) The effects of acute and chronic stress on the levels of reproductive hormones in the plasma of mature male brown trout, Salmo trutta L. Gen Comp Endocrinol 68: 249-259

Pinheiro J, Bates D, DebRoy S, Sarkar D, R Core Team (2016) nlme: linear and nonlinear mixed effects models. $\mathrm{R}$ package version 3.1-128. http://CRAN.R-project.org/ package $=$ nlme $>$

Quinn TP, McGinnity P, Reed TE (2015) The paradox of 'premature migration' by adult anadromous salmonid fishes: patterns and hypotheses. Can J Fish Aquat Sci 73:1-16

Raby GD, Cooke SJ, Cook KV, McConnachie SH and others (2013) Resilience of pink salmon and chum salmon to simulated fisheries capture stress incurred upon arrival

Editorial responsibility: Kevin Glover,

Bergen, Norway at spawning grounds. Trans Am Fish Soc 142:524-539

* Raby GD, Clark TD, Farrell AP, Patterson DA and others (2015) Facing the river gauntlet: understanding the effects of fisheries capture and water temperature on the physiology of coho salmon. PLOS ONE 10:e0124023

* Richard A, Bernatchez L, Valiquette E, Dionne M (2014) Telemetry reveals how catch and release affects prespawning migration in Atlantic salmon (Salmo salar). Can J Fish Aquat Sci 71:1730-1739

SBSM (Scientific Board for Salmon Management) (2016) Status for Norwegian salmon populations in 2016. Report 9. Scientific Board for Salmon Management, Trondheim. Available from: https://brage.bibsys.no/xmlui/handle/ 11250/2446896

Skaala Ø, Glover KA, Barlaup BT, Svåsand T, Besnier F, Hansen MM, Borgstrøm R (2012) Performance of farmed, hybrid and wild Atlantic salmon (Salmo salar) families in a natural river environment. Can J Fish Aquat Sci 69: 1994-2006

Svenning MA, Lamberg A, Dempson B, Strand R, Hanssen $\varnothing K$, Fauchald P (2017) Incidence and timing of wild and escaped farmed Atlantic salmon (Salmo salar) in Norwegian rivers inferred from video surveillance monitoring. Ecol Freshw Fish 26:360-370

Taggart JB, McLaren SM, Hay DW, Webb JH, Youngson AF (2001) Spawning success in Atlantic salmon (Salmo salar L.): a long-term DNA profiling-based study conducted in a natural stream. Mol Ecol 10:1047-1060

Thorstad EB, Næsje TF, Fiske P, Finstad B (2003) Effects of hook and release on Atlantic salmon in the River Alta, northern Norway. Fish Res 60:293-307

Thorstad EB, Næsje TF, Leinan I (2007) Long-term effects of catch-and-release angling on ascending Atlantic salmon during different stages of spawning migration. Fish Res 85:316-320

Weiner GS, Schreck CB, Li HW (1986) Effects of low pH on reproduction of rainbow trout. Trans Am Fish Soc 115: 75-82

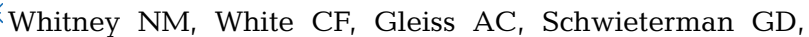
Anderson P, Hueter RE, Skomal GB (2016) A novel method for determining post-release mortality, behavior, and recovery period using acceleration data loggers. Fish Res 183:210-221

Submitted: February 9, 2017; Accepted: June 19, 2017 Proofs received from author(s): August 22, 2017 